\title{
Çokkültürlülük ve Yurtseverlik Bağlamında Azınlık Öğrencilerinin Tarih Dersleriyle Illgili Algıları
}

\section{Perception of Minority Students about History Lessons in the Context of Multiculturalism and Patriotism}

\author{
Fatih YAZICl ${ }^{*}$ \\ Yücel KABAPINAR**
}

\begin{abstract}
Öz: Bu araştırmada, Türkiye'deki azınlık okullarına devam eden lise öğrencilerinin tarih dersleriyle ilgili görüşlerinin çokkültürlülük ve yurtseverlik bağlamında değerlendirilmesi amaçlanmıştır. Araştırmanın çalışma grubunu kasti örneklem yöntemiyle seçilen, İstanbul'un çeşitli ilçelerindeki azınlık okulunda öğrenim gören 199 öğrenci oluşturmaktadır. Bu çalışma grubundan veri toplamak amacıyla araştırmacılar tarafından geliştirilen Çokkültürlülük Tutum Ölçeği, Yurtseverlik Ölçeği ve tarih derslerini kendi kimlikleri açısından değerlendirmelerini amaçlayan bir anket uygulanmıştır. Verilerin analizinde aritmetik ortalama, standart sapma ve $t$-testi kullanılmıştır. Araştırmaya katılan öğrencilerin çoğunluğu tarih derslerinde kendi kültürel kimliklerinin yeterince yer bulamadığını, bu kimliklere yer veren bölümlerde ise ötekileştirici bir söylemin kullanıldığını belirtmişlerdir. Tarih dersleri, kültürel farklılığa sahip öğrenciler için bu şekliyle, yurtseverlik duygusu oluşturmanın uzağında kalmaktadır.
\end{abstract}

Anahta
Azınlık Okulları

Abstract: The purpose of this study is to evaluate perceptions of students who attend minority school with respect to history lessons in the context of multiculturalism and patriotism in Turkey. The study group consists of intentionally chosen 199 students attending at different minority schools in Istanbul. Survey method was used in this study. The Multiculturalism Attitude Scale, Patriotism Scale and a questionnaire, developed by the researchers, examining cultural diversity in history lessons were used. In analyzing date, $t$ - test, arithmetic mean and standard deviation were used. The findings of the study indicated that existing cultural diversity in Turkey founds a very limited place in history lessons and a discriminatory or the other language or rhetoric toward different cultural groups was used in the history textbooks. For the

\footnotetext{
* Gaziosmanpaşa Üniversitesi, Eğitim Fakültesi, E-posta: yazicizade@gmail.com

** Marmara Üniversitesi, Eğitim Fakültesi, İlköğretim Bölümü, E-posta: ykabapinar@marmara.edu.tr
} 
same reason, history lessons were found too far from constituting patriotic emotions for culturally different students.

Keywords: Teaching History, Multiculturalism, Patriotism, Multicultural Education, Minority Schools

\section{Giriş}

20. yüzyıl boyunca ulus-devletler, sahip oldukları kültürel/etnik farklılıklar karşısında temelde iki farklı yaklaşım sergilemişlerdir. Birincisi, farklılıklara karşı asimilasyon politikaları izleme ya da görmezden gelme şeklinde gerçekleşmiştir. Böylece ülkedeki çoğunluk ya da devlet tarafından bir tehdit olarak değerlendirilen kültürel farklılıklar, gerçekte öyle olmasalar bile kimliklerine karşı oluşan baskı sonucunda zamanla bir tehdide dönüşebilmiştir. İkincisi, farklılıkları bir zenginlik olarak görüp, eşit saygı temelinde gerçekleşen yaklaşımdır. Çokkültürcülük bu seçeneklerden ikincisine karşılık gelen politikaları içermektedir.

Çokkültürcülük eşit yurttaşlık temelinde, aynı toplum içerisinde yaşayan farklı kültürlerin (çokkültürlülüğün) tanınması, bu kültürlere, egemen kültürle eşit haklar (ama aynı haklar olmayabilir) tanınarak onların toplumla bütünleşmelerinin sağlanmasına yönelik politikalar bütünüdür. Bu yönüyle aynı toplum içerisinde yaşayan, birbirinden farklı kültürel kimliklere sahip grupların, birbirleriyle olan ilişkilerini çatışma içerisine girmeden sağlıklı bir biçimde sürdürmelerinin politik yollarını arar. Çokkültürlü politikalar dâhilinde kültürel/etnik farklılığı olan topluluklardan, kendi kültürel değerlerinden vazgeçerek egemen/hâkim kültüre asimile olmaları ve onun değerlerini kabul etmeleri beklenmez. Bununla birlikte sahip oldukları kültürel değerler, eşit ölçüde saygıyı hak ettiği düşünüldüğünden, onları korumaları adına pozitif ayrımcılıktan yararlanmaları da sağlanabilir (Yazıcı, 2015: 29).

Çokkültürlü politikaların öznesi olan toplulukları bazıları, çeşitli nedenlerle egemen toplumdan dışlanmış ya da kenara itilmiş çok çeşitli sosyal grupları da içine alacak şekilde tanımlar. Bu toplulukların başında ise azınlıklar gelmektedir. Azınlık kavramı sosyal bilim açısından, sayısal bir ayrım ya da farklılaşmanın ötesinde bir anlam ifade eder. Niteliksel olarak değerlendirildiğinde bir azınlık topluluğu, toplumun çoğunluğuna oranla daha dezavantajlıdır. Bu dezavantajlı konum, azınlık topluluk üyelerinin bir grup içi dayanışmaya ve aidiyet duygusuna sahip olmalarını sağlar. Bu 
sebeple Giddens (2008), dünyanın birçok ülkesinde çoğunluğu oluştursalar bile dezavantajı konumundan dolayı kadınları, bir azınlık grubu olarak ele alır.

Geniş anlamda azınlık kavramı, sosyolojik ve olgusal bir durumdur. Bu tanıma göre azınlık, bir toplulukta sayısal bakımdan azınlık oluşturan, başat olmayan ve çoğunluktan farklı niteliklere sahip olan grubu ifade eder (Oran (2010). Bu, azınlığın en genel tanımıdır ve eşcinseller gibi çeşitli gruplar da bu tanımın içerisine girer.

Azınlık kavramı, aynı zamanda, bazı nesnel ve öznel koşulları ifade etmek için kullanııı1:

a) Başta etnik, dinsel ve dilsel olmak üzere çoğunluktan çeşitli bakımlardan farklı olmak.

b) Ülke genelinde sayıca azınlık olmak. Böyle bir azınlığın, ülkenin belli bir bölgesinde çoğunluk olması bir şey fark ettirmez.

c) Hâkim çoğunluk/Başat (dominant) olmamak. Bazı gruplar ülke genelinde sayıca çoğunlukta olmakla birlikte yönetim ve yönetime katılma açısından azınlık durumundadırlar.

d) Yurttaş olmamak veya bazı yurttaşık haklarından yararlanamamak: bir ülkede uzun süredir yaşıyor olmalarına rağmen yurttaşlık hakları verilmeyen gruplar.

e) Azınlık bilincinin varlığı: Yukarıdaki dört unsur, azınlık olmanın nesnel koşullarını oluşturur. Bir de öznel koşul vardır: Nasıl ki sınıf bilinci olmadan sınıf olmaz, farklı olduğunun bilincine varmayan ve bu farklığı kimliğinin vazgeçilmez koşulu saymayan birey veya grup da azınlık oluşturmaz. Bu, azınlık kavramının öznel koşuludur ve bazı örneklerinde azınlık grubunu belirleyen ana unsurdur (Oran, 2010: 26-27).

Belirlenen bu koşullara rağmen, bir ülkenin çokkültürlü yapısını oluşturmada önemli bir etken olarak değerlendirilebilecek olan azınlıkların, tanımlanması ve kategorize edilmesi güçtür. Böyle bir kavramsallaştırmayı güçleştiren durum ise azınlık tanımı üzerindeki, sosyoloji, hukuk, siyaset bilimi ve yurttaşlık anlayışı gibi birçok değişkenin etkisidir (Yazıcı, 2015: 25). Buna karşın Türkiye'deki azınık tanımını belirleyen bazı geleneksel unsurlar da söz konusudur ki bunların başında Osmanlı'da

${ }^{1}$ Oran hukuksal açıdan azınlık kavramını açıklarken BM raportörü Capotorti'nin yaptığı tanımdan hareket eder. 
uygulanan "millet sistemi" gelmektedir. Osmanlı sosyal yapısı içerisinde kültürel farklılığa sahip topluluklar, yönetim kolaylığı sağlaması amacıyla, etnik kökenlerine bakılmadan mensup oldukları din ve mezhebe göre kategorize edilmişlerdi (Bozkurt, 1993: 50). Böylece Osmanlı toplum yapısında belirleyici etken din olmuştur. Her ne kadar Tanzimat'la birlikte millet sisteminden vazgeçilmiş gibi görünmekle birlikte, toplumun dine göre kategorizasyonu Tanzimat sonrasında, hatta Cumhuriyet döneminde de etkili olmuştur. Bu durum, Türkiye'de yerleşik azınlık tanımında da belirleyici olmuş, azınlık denilince ülkede yaşayan gayrimüslim unsurların anlaşılmasına neden olmuştur.

Türkiye'de yaşayan azılıkların statülerini belirlemede en önemli referans noktası olan Lozan Antlaşması'ndaki azınlık statüsünün oluşmasında da Osmanlı'daki millet sisteminin referansları kullanılmıştır. Buna göre toplumun dini kategorizasyonu esas alındığından, azınlık olarak ülkede yaşayan gayrimüslim vatandaşlar azınlık tanımlaması içerisine girmiştir (Yıldız, 2010: 137). Bununla birlikte Lozan'da azınlıklara tanınan haklar tüm gayrimüslim gruplar için geçerli olmasına karşın, Osmanlı toplum yapısı içerindeki üç geleneksel cemaat: Rumlar, Ermeniler ve Museviler bu haklardan yararlanabilmiş, Süryaniler, Keldaniler, Asuriler ve Yezidiler gibi bu geleneksel yapı içerisinde çok fazla yer almayan topluluklar Lozan'ın kendilerine tanıdıkları haklardan yararlanamamışlardır (Okutan, 2009: 68).

\section{Çokkültürlü Toplumlarda Yurtseverlik}

Çokkültürlü toplumların varlıklarını devam ettirebilmeleri adına önemi olan yurtseverlik, farklı bir kültürel/etnik topluluğa mensup kişilerin, kendi kültürel topluluklarına duydukları bağlııktan vazgeçmeden, toplumun tamamına bir bağlılık ya da aidiyet hissetmelerine olanak tanır. Nitekim Kymlicka (1998), ulusal bir azınlık üyesinin hem güçlü bir ulusal bilinç taşıyıp hem de güçlü bir, yurtseverlik duygusu ve büyük siyasi bünyeye bağlılık besleyebilmesini engelleyen zorunlu bir neden olmadığını gösteren, İsviçre gibi, istikrarlı çokuluslu devletlerin önemli örnekleri olduğundan söz eder. Bu yurtseverlik duygusu öylesine güçlüdür ki, İsviçreliler halkların bir federasyonu oldukları kadar, bazı yönlerden, tek bir “halk”tır.

Yurtseverliğin, çokkültürlü toplumlarda birliktelik oluşturabilmesinin bazı koşulları vardır. Bazıları yurtseverliğin tikel bir kültürle bütünleşmek yerine, yalnızca 
demokrasi ve hakların politik ilkelerini kabul etmeye dayanması gerektiğini öne sürer. Sıklıkla, ulus üyeliğine ilişkin bu kültürel olmayan kavrayışın ABD'deki "yurttaş temeline dayalı" ya da "anayasal" milliyetçiliği, liberal olmayan "etnik" milliyetçilikten ayıran şey olduğu söylenir (Kymlicka, 1998: 56). Bu noktada ele alınması gereken anayasal yurtseverlik ise, siyasi bağılığın normlar, değerler ve daha dolaylı olarak liberal demokratik bir anayasada öngörülen prosedürler üzerine kurulu olması gerektiği düşüncesine dayanır. Bu özelliği sebebiyle çokkültürlüleşen toplumlar için yurttaşlığa dayalı (civic), gayri-ulusal (veya belki de post-ulusal) bir sadakat biçimi olarak görülmeye başlanmıştır (Müller, 2012: 14). Parekh (2005: 104) de buna paralel olarak çokkültürlü bir toplumun çeşitlilikleri barındırdığından aidiyet duygusunun etnik temelli olamayacağını: ortak etnik, kültürel ya da benzeri özelliklere dayanamayacağını belirtir. "Fakat bu aidiyet siyasi olmalıdır ve siyasi topluluğa duyulan ortak bir bağlılığa dayanmalıdır. Toplumun bireyleri birbirlerine etnik grup olarak değil, ortak bir topluluk üyeliği aracııı̆ıyla bağlıdır. Onları birleştiren, ortak bir tarihsel topluluğa duydukları kendilerine özgü bağ|ııklarıdır".

\section{Çokkültürlülük Bağlamında Tarih Eğitimi}

20. yüzyıl boyunca yaşanan tecrübeler göstermiştir ki, toplum içerisindeki kültürel farklııkların görmezden gelinmesi, yok sayılması hatta "aslında farklı olmadıkları"nın iddia edilmesi, onların "sadakatlerini" sağlamamıştır. Uygulanan bu politikalardaki temel sorun, toplumu bir arada tutabilmenin yolunun, toplum içindeki farklııkların en aza indirilmesinden geçtiğinin düşünülmesidir. Oysaki bir arada tutan ama birleştirmeyen, ortaklıklar kadar farklılıkları da vurgulayan ve onlara değer veren bir yaklaşımla toplumsal birlikteliğin sürdürülmesi mümkün olabilir. Bunun için öncelikle siyasal yapının, kültürel farklıııkları göz önünde bulunduracak şekilde yeniden tasarlanması, siyasal iktidar tarafından uygulanacak her politikanın, ülkedeki kültürel farklıı̆ı kuşatıcı nitelikte olması gerekir. Kültürel farklıı̆̆ı göz önünde bulunduran politikaların başlıca uygulama alanlarından biri eğitimdir. Tarih eğitimi ise, hem geçmişe hem de günümüze bakışı içermesi bakımından çoğu kez ülkelerin siyasal ve eğitimsel ideallerini yansıtır. Bu açıdan, tarih eğitiminin toplumu bir arada tutan bağları güçlendirirken, birlik içinde çokluk dengesini nasıl koruyacağı ve yansıtacağı önemli bir sorundur (Yazıcı,2015: 15-16). 
Öncelikle eğitim politikalarını belirleyenlerin ve okulların, çokkültürcü demokrasiye uygun tarih öğretim yaklaşımları geliştirmeleri gerekir. Bu, öğretilebilecek tek bir tarih ve geçmişe karşı, tartışımaz bir bakış açısı olmayacağını anlamına gelir. Yalnızca otoriter devletler bu yaklaşımı titizlikle takip ederler ve ortalama bir başarıyla karşılaşırlar. Asında tarihçiler, birbirleriyle çelişen birçok tarih olduğunu çoktandır fark etmişlerdir. Grever'ın gözlemlediği gibi, tarih öğretimi, en başta ve öncelikle ulusinşanın bir aracı olarak, eleştirel bir disiplin olan tarihin altını oymak için kurgulanmıştır. Fakat tarih öğretiminin demokrasinin öğretiminde de bir araç olabileceği unutulmamalıdır (akt. Osler, 2009: 98). Çokkültürlü tarih öğretimini de tarihin, demokrasinin ve demokratik değerlerin öğretimine yardımcı olması noktasında değerlendirebiliriz.

Çokkültürlü bir tarih öğretimi, kültürel farklılığa sahip öğrencilerin kendilerini toplumun bir parçası hissetmeleri ya da çoğunluk kültürden öğrencilerin çokkültürlü bir toplumun koşullarına hazırlanmalarının yanı sıra, demokratik sınıf ortamlarında demokrasiyi deneyimleme fırsatı elde ederek, demokratik bir toplumun etkin yurttaşları haline gelmelerine de olanak tanır. Farklı kültürlerin, yaşam biçimlerinin ve bakış açılarının eşit ölçüde saygıyı hak ettiğine dayanan bir öğretim anlayışı çerçevesinde farklııklara saygı, hoşgörü gibi sosyal beceriler geliştirebilecek: ayrımcılık, ırkçılık, farklııklara saygı duymama gibi demokratik değerlerle çatışan tutumlardan kaçınabileceklerdir.

Türkiye'deki tarih öğretim ve yazım anlayışının, çokkültürlü eğitimin temel ilkeleriyle önemli ölçüde çatışığı, yapılan araştırmalarla ortaya konmuştur (Copeaux, 1998: Tekeli, 2007: Yazıcı, 2015). Bu durumun çoğunluk kültürden öğrencilerde olduğu gibi, azınlık öğrencileri üzerinde de bir takım etkilerinin olabileceğini öngörmek mümkündür. Lozan Antlaşması'nın 40. ve 41. Maddeleri ile azınlıkların her türlü okul ve benzeri eğitim öğretim kurumları açabilecekleri karara bağlanmıştır (Çapar, 2006: 287). 1926 tarihli genelgede ise, azınlık okullarında okutulacak olan Türkçe, Türk Tarihi ve Türk Coğrafyası derslerini verecek olan öğretmenlerin Bakanlıkça tespiti öngörülmüştür (Okutan, 2009: 167-168). İlgili kanunun bugünkü durumunda ise, tarihin de içinde bulunduğu kültür derslerine, MEB tarafından atanan Türk öğretmenlerin girmeleri, söz konusudur (Yazıcı, 2015). Dolayısıyla MEB'na bağlı tüm okullarla aynı tarih öğretim programını ve tarih ders kitaplarını uygulayan azınlık okulları, Türkiye'deki 
tarih öğretim anlayışının çokkültürlü eğitim bağlamındaki sınırlılıklarından doğrudan etkilenmektedir.

Mevcut tarih öğretim programları, çokkültürlü eğitimle ilgili önemli sınırlılıklar taşımakla birlikte, çokkültürlü eğitimin amaçlarından bazılarına dolaylı da olsa yer vermiştir. 2007 yılında hazırlanan tarih öğretim programlarının amaçları arasında 1993 programıyla aynı şekilde "Öğrencilerin kendilerini kuşatan kültür dünyaları hakkında meraklarını gidermek" (8) ifadesi, kültürel farklılıklarla ilgisi olmamakla birlikte kültürle ilgili olarak yer almıştır. Bununla birlikte "Barış, hoşgörü, karşılıklı anlayış, demokrasi ve insan hakları gibi temel değerlerin önemini kavratarak bunların korunması ve geliştirilmesi konusunda duyarlı olmalarını sağlamak" (12) gibi doğrudan kültürel haklara saygıya vurgu yapmayan, fakat onun paylaştığı değerlere göndermede bulunan amaçlar yer almıştır (TTKB, 2007: 4).

$\mathrm{Bu}$ çalışmanın amacı: Türkiye'deki azınlık okullarına devam eden lise öğrencilerinin tarih dersleriyle (tarih öğretim programı, ders kitapları, tarih öğretmeninin sınıf içi tutumu ve etkinlikleri, okul iklimi) ilgili görüşlerini, yukarıda tanımlanan çokkültürlülük ve yurtseverlik bağlamında değerlendirmektir. Böylece tarih derslerinin, kültürel farklılığa sahip öğrenciler için taşıdığı anlamın ortaya konulması amaçlanmaktadır.

Araştırmanın problem cümlesi “Türkiye'deki azınlık okullarına devam eden lise öğrencileri, tarih derslerini çokkültürlülük ve yurtseverlik bağlamında nasıl değerlendirmektedir?" şeklinde belirlenmiştir. Bu ana problem cümlesi çerçevesinde cevapları aranacak alt problemler ise şunlardır:

Türkiye'deki azınlık okullarına devam eden lise öğrencilerinin:

1- Çokkültürlülüğe ilişkin tutumlarının, demografik değişkenlere göre farklılaşma durumları nedir?

2- Yurtseverliğe ilişkin tutumlarının demografik değişkenlere göre farklılaşma durumları nedir?

3- Tarih derslerinin, Türkiye'deki kültürel farklılıkları kapsamasına ilişkin görüşleri nelerdir?

4- Tarih derslerinin, kültürel farklılığa sahip öğrencilerde yurtseverlik duygusu oluşturmadaki rolüne ilişkin görüşleri nelerdir? 
Tarih eğitimi, dünyanın birçok ülkesinde olduğu gibi Türkiye'de de, tarih öğretiminin disiplin dışı amaçlarının da bir gereği olarak, bireyin sosyalleşmesini, toplumsal yaşamın bir parçası haline gelmesini sağlamaya çalışır. Bu sosyalleşme süreci bir anlamda toplumsal aidiyete karşılık gelmektedir. Türkiye'de bu aidiyet duygusu, tarih eğitiminin etnik-dini çoğunlukçu bir kimlik üzerine kurgulanması ile oluşturulmaya çalışılmaktadır. Ulus-inşa sürecinin bir parçası olarak değerlendirebileceğimiz bu tarih eğitim anlayışının Türkiye gibi çokkültürlü bir toplumda, farklı kültürel/etnik topluluklardan öğrenciler üzerinde nasıl bir etki yarattığı, istenilen amacı gerçekleştirip gerçekleştirmediğini incelemek önem taşımaktadır.

\section{Yöntem}

\section{Araştırmanın Modeli}

Çalışmada, genel tarama modellerinden ilişkisel tarama modelinden yararlanılmıştır. Tarama modelinin bir türü olan ilişkisel tarama modeli, iki ve daha çok sayıdaki değişken arasında birlikte değişim varlığını ve/veya derecesini belirlemeyi amaçlayan araştırma modelidir (Karasar, 2005: 81). Ilişkisel tarama modelinin karşılaşııma türünün kullanıldığı bu çalışmada, en az iki değişken arasında bağımsız değişkene göre gruplar oluşturularak bağımlı değişkene göre gruplar arasında fark olup olmadığı incelenmişsir.

\section{Çalışma Grubu}

Araştırmanın çalışma grubunu, İstanbul'un çeşitli ilçelerindeki 6 ayrı azınlık okulunda öğrenim gören öğrenciler arasından kasti örneklem yöntemine göre seçilen 199 öğrenci oluşturmaktadır. Araştırmanın çalışma grubunda yer alan öğrencilere ilişkin demografik veriler Tablo 1'de görüldüğü gibidir.

Tablo 1

Çalışma Grubunda Yer Alan Öğrencilerin Demografik Özellikleri

\begin{tabular}{lcc}
\hline Cinsiyet & $\boldsymbol{f}$ & $\%$ \\
\hline Erkek & 73 & 37 \\
Kız & 117 & 60 \\
\hline
\end{tabular}




\begin{tabular}{lcc}
\hline $\begin{array}{l}\text { Boş } \\
\text { Sınıf }\end{array}$ & 9 & 3 \\
\hline 11. sınıf & 98 & 50 \\
12. sınıf & 94 & 48 \\
Boş & 7 & 2 \\
Külterel/Etnik Topluluk & & \\
\hline Ermeni & 185 & 93 \\
Rum & 9 & 5 \\
Boş & 5 & 2 \\
\hline Toplam & 199 & $\mathbf{1 0 0}$ \\
\hline
\end{tabular}

Tabloda görüldüğü üzere, araştırmaya 199 öğrenci katılmasına rağmen, bazı katılımcılar cinsiyet, sınıf ya da okul değişkenlerini (bu değişken öğrencinin ait olduğu kültürel/etnik topluluğu ifade etmede kullanılmıştır) belirtmediklerinden, bu öğrencilerin bilgileri yukarıdaki tabloda "boş" olarak kodlanmıştır. Bağımsız değişkenler arasında yer alan cinsiyet ve sınıf değişkeninin dengeli bir dağılım gösterdiği söylenebilir. Sınıf değişkeninin sadece 11. ve 12. sınıflardan oluşması, öğrencilerin ölçme araçlarında yer alan soruları anlama ve cevaplamada zorluk yaşamamaları adına, araştırmacılar tarafından belirlenen bir durumdur. Öğrencilerin kültürel/etnik topluluk değişkenine göre dağılımları incelendiğinde ise Ermeni öğrencilerin, çalışma grubunun önemli bir çoğunluğunu oluşturduğu görülmektedir. Bu durumun nedeni ise Ermeni cemaat okullarının ve bu okullardaki öğrenci sayısının Rum ve Musevi cemaat okullarına göre daha fazla olması, 1 Rum okulu dışında, Rum ve Musevi cemaat okullarının idarelerinin, kendi özel durumları sebebiyle araştırmaya katılmamış olmalarıdır.

\section{Veri Toplama Araçları}

Bu çalışmada, araştırma deseni doğrultusunda Çokkültürlü Tutum Ölçeği, Yurtseverlik Ö/çeği ve farklı kültürel gruplara mensup öğrencilerin tarih derslerini değerlendirmelerini amaçlayan bir anket olmak üzere üç farklı veri toplama aracı kullanılmıştır.

Çokkültürlü Tutum Ölçeği: Lise öğrencilerinin çokkültürlülük tutumlarını ölçmek amacıyla araştırmacı tarafından geliştirilmiştir. Ölçek geliştirme sürecinde ilgili 
literatürden, uzman görüşlerinden ve ayrıca Toth ve Vijver (2003) ile Breugelmans ve Vijver (2004) tarafından, çokkültürlü tutumları ölçmek amacıyla geliştirilen ölçeklerden, kültür farklılığı sebebiyle doğrudan Türkçeye adaptasyonları yapılmadan yararlanılmıştır. 22 maddeden oluşan ölçekte 8 madde ters kodlanmıştır. Tek boyutlu olarak öngörülen ölçek, 5 'li likert tipinde kurgulanmıştır. Ölçeğin tek boyutlu faktöriyel yapısını sınamak için açıklayıcı faktör analizi yapıımıştır.

Çokkültürlü Tutum Ölçeği'ne ilişkin elde edilen verilerin faktör analizine uygun bir dağılım gösterip göstermediğini belirlemek amacıyla öncelikle Kaiser Meyer Olkin (KMO) ve Bartlett testleri yapılmıştır. Yapılan analiz sonucunda Kaiser Meyer Olkin (KMO) değeri .85 olarak bulunmuştur. Bartlett testi sonucu ise 1144,55 $(p<0.05)$ olarak hesaplanmıştır. KMO'nun .60'dan yüksek, Bartlett testinin ise anlamlı çıkması verileri faktör analizi için uygun olduğunu gösterir (Büyüköztürk, 2008, 126). Bu çalışma için yapılan hesaplamalar, verilerin faktör analizi için yeterli olduğunu gösterdiğinden faktör analizi safhasına geçilmiştir.

Çokkültürlü Tutum Ölçeği'nin yapı geçerliliğini belirlemek amacıyla faktör analizi sırasında Varimax Döndürme Metodu uygulanmıştır. Yapılan faktör analizinde ölçeğin faktör yapısı tek faktörle sınırlandırılarak incelenmiştir. Tek faktörde açıklanan varyans oranı \% 31.142 olarak hesaplanmıştır. Ölçeğin güvenilirliği için açıklanan varyans oranının \% 30'un üzerinde olması beklenir (Büyüköztürk, 2008, 125). Bu çalışmada elde edilen \% 31'lik varyans oranı kabul edilebilir ölçülerdedir.

Ölçme aracının güvenilirliği için faktör yüklerinin, 300'ün üzerinde olması beklenir (de Vaus, 2002: Şencan, 2005: Büyüköztürk, 2008). Yapılan faktör analizi sonucunda ise ölçek maddelerine ilişkin faktör yüklerinin $0.308-0.672$ arasında değiştiği görülmektedir. Bu durum ölçeğin yapı geçerliliğini sağladığını göstermektedir.

Faktör analizi sonucunda yapı geçerliliğini sağladığı ortaya konan ölçeğin iç tutarlıı̆̆ının belirlenmesi amacıyla Cronbach Alpha katsayısına bakılmıştır. Her bir maddenin varyansına dayalı olarak hesaplanan Cronbach Alfa iç tutarlıık katsayısı Çokkültürlü Tutum Ölçeği için 0.88 olarak hesaplanmıştır. Literatüre göre iç tutarlılık katsayısının 0.70 ve daha yukarı olması test güvenilirliği için genel olarak yeterli görülmektedir (Büyüköztürk, 2008: 171). Dolayısıyla ölçek için hesaplanan Cronbach Alfa iç tutarlıık katsayısı yeterli görülen değerlerin üzerindedir. 
Yurtseverlik Ölçeği: Lise öğrencilerinin yurtseverlik tutumlarını ölçmek amacıyla araştırmacı tarafından geliştirilmiştir. Ölçek geliştirme sürecinde Kosterman ve Feshbach'ın (1989) yurtseverlik ve milliyetçilik arasındaki ayrımı ortaya koymayı amacıyla geliştirdiği ölçeğin (Patriotism/Nationalism Questionare) yurtseverliğe ilişkin alt ölçeğinden, ilgili literatürden ve uzman görüşlerinden yararlanılmıştır. 16 maddeden oluşan ölçekte 4 madde ters kodlanmıştır. Tek boyutlu olarak öngörülen ölçek, $5^{\prime}$ li likert tipinde kurgulanmıştır.

Yurtseverlik Ölçeği'ne ilişkin elde edilen verilerin faktör analizine uygun bir dağılım gösterip göstermediğini belirlemek amacıyla öncelikle Kaiser Meyer Olkin (KMO) ve Bartlett testleri yapılmıştır. Yapılan analiz sonucunda Kaiser Meyer Olkin (KMO) değeri ,90 olarak bulunmuştur. Bartlett testi sonucu ise 4541,47 ( $p<0.05$ ) olarak hesaplanmıştır. Bu ölçek için yapılan hesaplamalar, verilerin faktör analizi için yeterli olduğunu gösterdiğinden faktör analizine geçilmiştir.

Yapılan faktör analizinde ölçeğin faktör yapısı tek faktörle sınırlandırılarak incelenmiştir. Tek faktörde açıklanan varyans oranı \% 48.332 olarak hesaplanmış, faktör yüklerinin ise 0,476-0,817 arasında değiştiği görülmektedir. Bu durum ölçeğin yapı geçerliliğini sağladığını göstermektedir. Cronbach Alfa iç tutarlıık katsayısı da Yurtseverlik Ölçeği için .93 olarak hesaplanmıştır.

Anket: Farklı kültürel gruplara mensup öğrencilerin tarih derslerini, kendi kültürel/etnik kimlikleri açısından değerlendirmelerini ve çokkültürcü bir tarih eğitiminin nasıl olması gerektiğine dair önerilerini değerlendirmeyi amaçlayan üçüncü veri toplama aracı yine araştırmacı tarafından ilgili literatür ve uzman görüşleri doğrultusunda geliştirilmiş olup ölçekten ziyade anket özelliği taşımaktadır. 19 maddeden oluşan anket formu 5'li likert tipindedir.

\section{Verilerin Analizi}

Veri toplama araçlarıyla elde edilen verilerin çözümlenmesinde ölçek toplam puanlarının ortalamaları, ölçekler ve ankette yer alan maddelerin aritmetik ortalama ve standart sapma değerleri, gruplar arası farkların analizinde ise $t$-testi kullanılmıştır. 


\section{Bulgular}

Türkiye'deki Farklı Kültürel Gruplardan Lise Öğrencilerinin Çokkültürlülüğe İlişkin Tutumları

Araştırmanın birinci alt problemine cevap bulmak amacıyla katılımcılara Çokkültürlü Tutum Ölçeği uygulanmıştır. Ölçekte yer alan maddelerin ortalama ve standart sapma değerleri Tablo 2'de yer almaktadır.

Tablo 2

Çokkültürlü Tutum Ölçeğine Illişkin Maddelerin Ortalama ve Standart Sapma Değerleri

\begin{tabular}{|c|c|c|c|}
\hline Çokkültürlü Tutum Ölçeği & $\mathbf{n}$ & $\bar{X}$ & ss \\
\hline 1. Madde & 194 & 4,51 &, 91 \\
\hline 2. Madde & 191 & 4,49 & ,85 \\
\hline 3. Madde & 192 & 4,08 & 1,22 \\
\hline 4. Madde & 193 & 4,33 & ,88 \\
\hline 5. Madde & 189 & 4,36 & ,94 \\
\hline 6. Madde & 191 & 3,97 & ,98 \\
\hline 7. Madde & 189 & 4,04 & 1,14 \\
\hline 8. Madde & 193 & 4,16 & ,98 \\
\hline 9. Madde & 184 & 3,20 & 1,16 \\
\hline 10. Madde & 190 & 4,02 & 1,04 \\
\hline 11. Madde & 191 & 3,27 & 1,25 \\
\hline 12. Madde & 191 & 4,02 & ,97 \\
\hline 13. Madde & 189 & 4,24 & 1,04 \\
\hline 14. Madde & 189 & 4,10 &, 96 \\
\hline 15. Madde & 190 & 3,81 & 1,21 \\
\hline 16. Madde & 191 & 4,14 & ,93 \\
\hline 17. Madde & 192 & 4,66 & ,82 \\
\hline 18. Madde & 190 & 3,99 & 1,22 \\
\hline 19. Madde & 192 & 4,50 & ,87 \\
\hline 20. Madde & 192 & 4,32 & 1,02 \\
\hline 21. Madde & 178 & 3,70 & 1,23 \\
\hline 22. Madde & 192 & 4,51 &, 76 \\
\hline Toplam & 150 & 4,09 &, 55 \\
\hline
\end{tabular}


Ölçeğe verilen puanlar incelendiğinde ölçek ortalamasının 4,09 (ss= .55) gibi 5’li likert tipine göre yüksek bir puan ortalamasına sahip olduğu görülmektedir. Şüphesiz bu durumda, ölçeği puanlayan öğrencilerin Türkiye'nin geneline göre farklı kültürel/etnik gruplardan olmaları ve bu sebeple çokkültürlülüğün doğrudan muhatapları olmaları etkilidir.

Azınlık okullarına devam eden öğrencilerin çokkültürlü tutumlarının cinsiyetlerine göre farklılaşma durumunu belirlemek amacıyla ilişkisiz grup t-testi yapılmıştır. Yapılan analiz sonuçları Tablo 3'te belirtilmiştir.

Tablo 3

Kültürel/Etnik Farklıı̆a Sahip Öğrencilerin Çokkültürlü Tutumlarının Cinsiyet Değişkenine Göre Farklılaşma Durumu

\begin{tabular}{lllcccc}
\hline Gruplar & $\mathbf{n}$ & $\bar{X}$ & ss & \multicolumn{3}{c}{ t Testi } \\
\cline { 5 - 7 } & & & & $\mathbf{t}$ & Sd & $\mathbf{p}$ \\
\hline Kız & 85 & 4,20 &, 48 & 3,00 & 145 &, 003 \\
Erkek & 62 & 3,93 &, 61 & & & \\
\hline
\end{tabular}

Yapılan t-testi sonuçlarına göre, kültürel/etnik farklılığa sahip öğrencilerin Çokkültürlü Tutum Ölçeği'ne verdikleri puanların cinsiyet değişkenine göre farklılaşığı, kız öğrencilerin çokkültürlü tutumlarının erkek öğrencilere göre daha yüksek olduğu ve aralarındaki farkın $p<.01$ düzeyinde anlamlı olduğu görülmüştür.

Kültürel/etnik farklılığa sahip öğrencilerin çokkültürlü tutumlarının sınıf değişkenine göre farklılaşma durumunu belirlemek amacıyla ilişkisiz grup $t$-testi yapılmıştır. Yapılan analiz sonuçları Tablo 4'te belirtilmiştir.

Tablo 4

Kültürel/Etnik Farklıı̆̆a Sahip Öğrencilerin Çokkültürlü Tutumlarının Sınıf Değişkenine Göre Farklılaşma Durumu

\begin{tabular}{llllccc}
\hline Gruplar & $\mathbf{n}$ & $\bar{X}$ & ss & \multicolumn{3}{c}{ t Testi } \\
\cline { 5 - 7 } & & & & $\mathbf{t}$ & $\mathbf{S d}$ & $\mathbf{p}$ \\
\hline 11. sinıf & 77 & 4,10 &, 56 &,- 104 & 146 &, 917 \\
12. sinıf & 71 & 4,11 &, 49 & & & \\
\hline
\end{tabular}


Yapılan $t$-testi sonuçlarına göre, kültürel/etnik farklılığa sahip öğrencilerin Çokkültürlü Tutum Ölçeği'ne verdikleri puanların sınıf değişkenine göre anlamlı biçimde farklılaşmadığı görülmektedir.

Öğrencilerin çokkültürlü tutumlarının, farklı kültürlerden arkadaş edinme değişkenine göre farklılaşma durumunu belirlemek amacıyla öğrencilere "Arkadaşlarınızdan yüzde (\%) kaçı sizden farklı bir kültürel gruba mensuptur?" şeklindeki soru yöneltilmiştir. Öğrencilerin bu soruya vermiş oldukları cevapların dağılımı göz önünde bulundurularak, "Hiç, 1-25, 26-50, 51-75, 76-100 şeklindeki cevaplar 0-25 ile 26 ve üzeri şeklinde iki grupta toplanmıştır. Öğrencilerin farklı kültürlerden arkadaş edinme oranları ile çokkültürlülük tutumları arasındaki ilişkiyi belirlemek amacıyla ilişkisiz grup $t$-testi yapılmıştır. Yapılan analiz sonuçları Tablo 5'te belirtilmiştir.

Tablo 5

Öğrencilerin Çokkültürlü Tutumlarının, Kendisinden Farklı Kültürel Gruplardan Arkadaş Edinme Değişkenine Göre Farklılaşma Durumu

\begin{tabular}{lllllll}
\hline Gruplar & $\mathbf{n}$ & $\bar{X}$ & ss & \multicolumn{3}{c}{ t Testi } \\
\cline { 5 - 7 } & & & & $\mathbf{t}$ & Sd & $\mathbf{p}$ \\
\hline $0-25$ & 65 & 4,05 &, 53 &,- 813 & 141 &, 417 \\
26 ve & 78 & 4,13 &, 55 & & & \\
üzeri & & & & & & \\
\hline
\end{tabular}

Yapılan ilişkisiz grup $t$-testi analizi sonucunda, öğrencilerin arkadaş grubunda, kendisinden farklı kültürel/etnik gruplardan bireylerin oranı ile çokkültürlü tutumları arasında anlamlı bir ilişki bulunamamıştır.

\section{Türkiye'deki Farklı Kültürel Gruplardan Lise Öğrencilerinin Yurtseverliğe İlişkin Tutumları}

Araştırmanın ikinci alt problemine cevap bulmak amacıyla katılımcılara Yurtseverlik Ölçeği uygulanmıştır. Ölçekte yer alan maddelerin ortalama ve standart sapma değerleri Tablo 6'da yer almaktadır. 
Tablo 6

Yurtseverlik Ölçeği'ne Illişkin Maddelerin Ortalama ve Standart Sapma Değerleri

\begin{tabular}{lccc}
\hline Yurtseverlik Ölçeği & $\mathbf{n}$ & $\bar{X}$ & $\mathbf{s s}$ \\
\hline 1. Madde & 183 & 2,81 & 1,13 \\
2. Madde & 189 & 3,01 & 1,21 \\
3. Madde & 189 & 3,32 & 1,22 \\
4. Madde & 188 & 3,03 & 1,19 \\
5. Madde & 186 & 3,02 & 1,18 \\
6. Madde & 184 & 2,79 & 1,32 \\
7. Madde & 182 & 2,39 & 1,21 \\
8. Madde & 188 & 3,04 & 1,23 \\
9. Madde & 192 & 2,38 & 1,26 \\
10. Madde & 187 & 2,77 & 1,27 \\
11. Madde & 187 & 2,64 & 1,19 \\
12. Madde & 187 & 3,18 & 1,06 \\
13. Madde & 190 & 1,92 & 1,06 \\
14. Madde & 191 & 3,26 & 1,15 \\
15. Madde & 184 & 2,75 & 1,20 \\
16. Madde & 188 & 3,13 & 1,23 \\
\hline Ölçek Ortalama Puanı & $\mathbf{1 5 7}$ & $\mathbf{2 , 8 1}$ &, $\mathbf{8 3}$ \\
\hline
\end{tabular}

Ölçeğe verilen puanlar incelendiğinde, ölçek ortalamasının 2,81 (ss=,83) gibi 5’li likert tipine göre ortalama bir puana sahip olduğu görülmektedir.

Kültürel/etnik farklılığa sahip öğrencilerin yurtseverlik tutumlarının cinsiyetlerine göre farklılaşma durumunu belirlemek amacıyla ilişkisiz grup $t$-testi yapılmıştır. Yapılan analiz sonuçları Tablo 7'de belirtilmiştir. 
Tablo 7

Kültürel/Etnik Farklılığa Sahip Öğrencilerin Yurtseverlik Tutumlarının Cinsiyet Değişkenine Göre Farklılaşma Durumu

\begin{tabular}{lllcccc}
\hline Gruplar & $\mathbf{n}$ & $\bar{X}$ & ss & \multicolumn{3}{c}{ t Testi } \\
\cline { 5 - 7 } & & & & $\mathbf{t}$ & $\mathbf{S d}$ & $\mathbf{p}$ \\
\hline Kız & 88 & 2,84 &, 86 &, 076 & 152 &, 940 \\
Erkek & 66 & 2,83 &, 77 & & & \\
\hline
\end{tabular}

Yapılan t-testi sonuçlarına göre, kültürel/etnik farklılığa sahip öğrencilerin Yurtseverlik Ölçeği'ne verdikleri puanların cinsiyet değişkenine göre anlamlı bir biçimde farklılaşmadığı görülmüştür.

Kültürel/etnik farklılığa sahip öğrencilerin yurtseverlik tutumlarının sınıf değişkenine göre farklılaşma durumunu belirlemek amacıyla ilişkisiz grup $t$-testi yapılmıştır. Yapılan analiz sonuçları Tablo 8'de belirtilmiştir.

Tablo 8

Kültürel/Etnik Farklılığa Sahip Öğrencilerin Yurtseverlik Tutumlarının Sınıf Değişkenine Göre Farklılaşma Durumu

\begin{tabular}{lcccccc}
\hline Gruplar & $\mathbf{n}$ & $\bar{X}$ & ss & \multicolumn{3}{c}{$\mathbf{t}$ Testi } \\
\cline { 5 - 7 } & & & & $\mathbf{t}$ & $\mathbf{S d}$ & $\mathbf{p}$ \\
\hline 11. SInıf & 83 & 2,73 &, 82 & $-1,32$ & 153 &, 189 \\
12. sinıf & 72 & 2,90 &, 80 & & & \\
\hline
\end{tabular}

Yapılan t-testi sonuçlarına göre, kültürel/etnik farklılığa sahip öğrencilerin Yurtseverlik Ölçeği'ne verdikleri puanların sınıf değişkenine göre anlamlı biçimde farklılaşmadığı görülmektedir.

Öğrencilerin yurtseverlik tutumlarının, farklı kültürlerden arkadaş edinme değişkenine göre farklılaşma durumunu belirlemek amacıyla öğrencilere "Arkadaşlarınızdan yüzde (\%) kaçı sizden farklı bir kültürel gruba mensuptur?" şeklindeki soru yöneltilmiştir. Öğrencilerin bu soruya vermiş oldukları cevapların dağılımı göz önünde bulundurularak, "Hiç, 1-25, 26-50, 51-75, 76-100 şeklindeki cevaplar 0-25 ile 26 ve üzeri şeklinde iki grupta toplanmıştır. Öğrencilerin farklı kültürlerden arkadaş edinme oranları ile yurtseverlik tutumları arasındaki ilişkiyi 
belirlemek amacıyla ilişkisiz grup $t$-testi yapılmıştır. Yapılan analiz sonuçları Tablo 7'de belirtilmiştir.

Tablo 9

Öğrencilerin Yurtseverlik Tutumlarının, Kendisinden Farklı Kültürel Gruplardan Arkadaş Edinme Değişkenine Göre Farklılaşma Durumu

\begin{tabular}{llllccc}
\hline Gruplar & $\mathbf{n}$ & $\bar{X}$ & ss & \multicolumn{3}{c}{ t Testi } \\
\cline { 5 - 7 } & & & & $\mathbf{t}$ & Sd & $\mathbf{p}$ \\
\hline $0-25$ & 69 & 2,62 &, 84 & $-2,443$ & 146 &, 016 \\
26 ve & 79 & 2,95 &, 79 & & & \\
üzeri & & & & & & \\
\hline
\end{tabular}

Yapılan ilişkisiz grup t-testi analizi sonucunda, öğrencilerin arkadaş grubunda, kendisinden farklı kültürel/etnik gruplardan bireylerin oranı ile yurtseverlik tutumları arasında $p<.05$ düzeyinde anlamlı bir ilişki bulunmuştur. Yani toplumun geneline göre farklı kültürel/etnik gruplardan öğrencilerin kendinden farklı kültürel/etnik gruplardan bireyler ile arkadaşlık oranı arttıkça yurtseverlik tutumları da artmaktadır. Bu durum, sadece kendi kültürel/etnik topluluğundan olan bireylerle arkadaşlık edenlere göre, kendinden farklı/kültürel etnik gruplardan bireylerle arkadaşlık edenlerin ülkenin ve o ülkede yaşayan toplumun tamamına karşı daha güçlü bir bağlılık ya da aidiyet yarattığı şeklinde yorumlanabilir. Böylece kendi kültürel/etnik topluluğu sınırları içerisinde sosyalleşmek, kültürel toplulukları gettolaşmaya götürdüğü gibi onların, toplumun tamamına karşı bir bağlılık ve aidiyet geliştirmelerini de engellemektedir.

\section{Türkiye'deki Farklı Kültürel Gruplardan Lise Öğrencilerinin, Tarih Derslerinin Türkiye'deki Kültürel Farklılıkları Kapsamasına İlişkin Görüşleri}

Araştırmanın üçüncü alt problemine cevap bulmak amacıyla öğrencilere, tarih programlarının, ders kitaplarının ve tarih öğretmenlerinin, Türkiye'nin çokkültürlü yapısını oluşturan kültürel farklılıklara nasıl yaklaştığına ilişkin 5'li likert tipinde düzenlenmiş anket maddeleri yönlendirilmiş, elde edilen veriler Tablo 8'de gösterilmiştir. 
Tablo 10

Anket Maddelerinin Ortalama ve Standart Sapma Değerleri

\begin{tabular}{lllll}
\hline Anket Maddeleri & n & $\bar{X}$ & Ss
\end{tabular}

40. Tarih ders kitaplarının kültürel/etnik farklılığımı dikkate aldığını düşünüyorum.

$183 \quad 2,30 \quad 1,33$

41. Tarih öğretmenlerimizin kültürel/etnik farklıığımı dikkate aldığını düşünüyorum.

42. Tarih derslerinin Türkiye'deki tüm kültürel/etnik grupları kapsadığını düşünüyorum.

45. Tarih derslerinde kültürel/etnik kimliğime yeterince yer verilmemektedir.

$180 \quad 3,26 \quad 1,33$

46. Tarih derslerinde, Türkiye'nin kültürel olarak farklı

$177 \quad 3,97 \quad 98$ topluluklardan oluştuğunun daha çok vurgulanması gerekir.

47. Tarih derslerinin kültürel/etnik farklılık taşıyan öğrencilere uygun olduğunu düşünmüyorum.

48. Tarih derslerinde sadece taşıdığım kültürel/etnik kimliğin tarihini görmek isterdim.

49. Tarih derslerinin kapsamı Türkiye'deki tüm kültürel/etnik grupları kapsayacak şekilde yeniden tasarlanmalıdır.

50. Tarih ders kitaplarının kendi kültürel/etnik kimliğimi ele alma biçimi, beni rahatsız ediyor.

53. Tarih öğretmenlerimin kültürel/etnik kimliğimi tanımak için yeterince çaba harcadığını düşünüyorum.

54. Paylaştığım kültürel/etnik kimliğin bakış açıSı, tarih derslerine yansımaktadır.

55. Tarih dersleri, ait olduğum kültürel/etnik geçmişi görmezden gelmektedir.

56. Tarih dersleri sadece ortak değerlere yer vermelidir.

$185 \quad 2,60 \quad 1,20$

$182 \quad 4,08 \quad 1,04$

$182 \quad 3,54 \quad 1,31$

$183 \quad 3,08 \quad 1,15$

$1752,78 \quad 1,16$

$1763,41 \quad 1,22$

$180 \quad 3,13 \quad 1,20$

57. Tarih derslerinde, bu ülkede yaşayan farklı kültürel/etnik gruplara yer verilmesi ülkede çatışma yaratır.

$182 \quad 2,27 \quad 1,21$

58. Kültürel/etnik kimliğim açısından tarih derslerinde herhangi $185 \quad 2,81 \quad 1,28$ bir rahatsızlık yaşamıyorum.

Tablo incelendiğinde "Tarih derslerinin kapsamı Türkiye'deki tüm kültürel/etnik grupları kapsayacak şekilde yeniden tasarlanmalıdır" şeklindeki 49. maddenin 4,08 ortalama ile en yüksek değere sahip olduğu görülmektedir. Bu durum kültürel farklıığa 
sahip öğrenciler tarafından, tarih derslerinin kendi kültürlerinin daha çok dikkate alındığı bir düzenlemeye ne kadar ihtiyacı olduğunu göstermesi bakımından önemlidir. Böyle bir düzenlemeyi gerekli kılan durumun ise, tarih ders kitaplarında kültürel farklılıkların ele alınış biçiminden kaynaklandığı, "Tarih ders kitaplarının kendi kültürel/etnik kimliğimi ele alma biçimi beni rahatsız ediyor" şeklinde düzenlenen 50. maddenin, 3,54 ortalama ile en yüksek değere sahip ikinci madde olmasından anlaşılmaktadır. Bununla birlikte "Tarih derslerinin kültürel/etnik farklılık taşıyan öğrencilere uygun olduğunu düşünmüyorum" şeklindeki 47. maddenin $(\bar{X}=3,46)$ ve "Tarih dersleri, ait olduğum kültürel/etnik geçmişi görmezden gelmektedir" şeklindeki 55. maddenin $(\bar{X}=3,41)$ yüksek ortalamaya sahip diğer maddeler olmaları da bu durumu desteklemektedir. Bununla birlikte "Tarih derslerinde, bu ülkede yaşayan farklı kültürel/etnik gruplara yer verilmesi ülkede çatışma yaratır” şeklindeki 57. maddenin en düşük ortalamaya sahip madde olması ( $\bar{X}=2,27$ ), kültürel farklılığa sahip öğrencilere göre tarih derslerinde kültürel farklılıklara yer verilmesi yönünde yapılacak bir düzenleme, ülkenin birliği konusunda bir sorun yaratmayacaktır.

Yukarıda yer alan anket maddeleri arasında en düşük ortalamaya sahip ikinci maddenin "Tarih ders kitaplarının kültürel/etnik farklılı̆ımı dikkate aldığını düşünüyorum" şeklindeki 40. Madde olması ( $\bar{X}=2,30)$, kültürel farklııığa sahip öğrencilerin, tarih öğretiminin önemli bir unsuru olan ders kitaplarından duyduğu rahatsızlı̆ı̆ı göstermektedir. Ayrıca anket sonuçlarına göre 3,54 ortalama ile en yüksek ikinci değere sahip madde olan, "Tarih ders kitaplarının kendi kültürel/etnik kimliğimi ele alma biçimi beni rahatsız ediyor" şeklindeki 50. madde, araştırmaya katılan öğrencilere göre, sınırlı bir oranda ve belli çerçevelerde ele alınan kültürel farklııkların, ders kitaplarında yer alma biçimi ve bu farklııklarla ilgili ders kitabının söylemi sorununu gündeme getirmektedir.

Araştırmaya katılan öğrencilerin tarih ders kitaplarıyla ilgili yapmış oldukları bu değerlendirmelerin yanı sıra, tarih öğretiminin bir diğer -ve belki de en önemli- unsuru olan öğretmenin kültürel farklılıklar konusundaki yaklaşımını da değerlendirmek gerekir. Bununla ile ilgili olarak sorulan "Tarih öğretmenlerimizin kültürel/etnik farklıığımı dikkate aldığını düşünüyorum" şeklindeki 41. maddenin, tarih ders kitapları ile kıyaslandığında nispeten $(\bar{X}=2,30)$ daha yüksek bir ortalama sahip olması ( $\bar{X}$ $=3,25$ ), öğretmenlerin kültürel farklııklara karşı yaklaşımının ders kitaplarından daha olumlu olduğunu göstermektedir. 
Türkiye'deki Farklı Kültürel Gruplardan Lise Öğrencilerinin Tarih Derslerinin Kültürel Farklıı̆̆a Sahip Öğrencilerde Yurtseverlik Duygusu Oluşturmadaki Rolüne İlişkin Görüşleri

Araştırmanın dördüncü alt problemine cevap aramak amacıyla veri toplama araçları arasında yer alan ankette, üç soru yer almaktadır. Elde edilen veriler, aşağıdaki şekliyle tablolaştırıımıştır.

Tablo 11

Tarih Derslerinin Yurtseverlik Duygusu Oluşturmasına İlişkin Anket Verileri

Anket Maddeleri

44. Tarih dersleri Türkiye'ye bağlıı̆̆ımı kuvvetlendirmektedir.

51. Kendimi bu ülkenin bir parçası olarak hissetmemde tarih derslerinin etkisi büyüktür.

52. Tarih dersleri bana kendimi öteki olarak hissettiriyor. n $\bar{X}$ Ss

$1822,051,20$

$1832,041,11$

$183 \quad 3,16 \quad 1,33$

Tabloda görüldüğü üzere 44. ve 51. soruların aldıkları ortalama puanlar, araştırmaya katılan öğrencilerin tarih derslerinin, ülkeye olan bağlılıklarını kuvvetlendirdiği $(\bar{X}=2,05)$ ya da kendilerini ülkenin bir parçası olarak hissetmelerini sağladığı ifadelerine katılmadıklarını ( $\bar{X}=2,04)$ göstermektedir.

\section{Sonuç}

Çağdaş tarih öğretimi, disiplin içi amaçları ile bireylere tarihsel beceriler kazandırmaya çalışırken disiplin dışı amaçları çerçevesinde bireyin sosyalleşmesini ve kültür aktarımını da beraberinde getirmektedir. Her ne kadar tarih öğretiminin araçsallaşmaması için disiplin dışı amaçların görece sınırlı olması gerekse de, tarih eğitimi ile bireyin sosyalleşmesi ve toplumsal aidiyet oluşturması arasındaki ilişki kaçınılmazdır. Fakat Türkiye gibi, tarih öğretiminin ulus-inşanın bir aracı olarak görüldüğü ve dini/etnik çoğunlukçu anlayışa göre kurgulandığı bir ülkede tarih 
derslerinin, çoğunluk kimliğini paylaşmayan öğrenciler için bir toplumsallaşma aracı olması güçtür. Nitekim araştırma sonuçları da bu durumu doğrulamaktadır.

Araştırmaya katılan öğrencilerin, 5'li likert tipine göre geliştirilen Çokkültürlü Tutum Ölçeği'ne verdikleri 4,09'luk ortalama puan, çokkültürlü tutumlarının yüksek olduğunu göstermektedir. Bu durumun temelde iki nedeni olabilir. Birincisi: çoğunluğunu oluşturmadıkları bir toplumda çokkültürlü tutum ve politik uygulamaların doğrudan öznesi olarak, bu tutum ve uygulamaların, sahip olduklarını düşündükleri dezavantajları ortadan kaldırabileceğine dair beklentileridir. İkinci neden ise, aynı toplum içerisinde bir arada yaşadıkları kendilerinden farklı etnik kimliklerin kültürlerinden rahatsızıık duymamaları şeklinde değerlendirilebilir.

t- testi kullanılarak yapılan ilişkisel analizlerde, araştırmaya katılan öğrencilerin çokkültürlülük tutumlarının cinsiyet değişkenine göre kız öğrenciler lehine anlamlı biçimde farklılaştığı görülmüştür. Kız öğrencilerin, erkek öğrencilere oranla çokkültürlülük tutumlarının daha yüksek puana sahip olması sosyal becerilerle ilgili bir durum olarak değerlendirilebilir. Yapılan araştırmalar göstermektedir ki kız çocukları ile erkek çocuklarının sosyal becerileri, okul öncesi dönemden itibaren önemli farklııklar göstermektedir. Kız çocuklarının sözel etkinlikleri daha fazla sergiledikleri, saldırgan ve rahatsız edici sosyal davranışlarının daha az olduğu gözlemlenmiştir (Tüy, 1999). Bu durumun temel nedeninin kız ve erkek çocukları arasındaki biyolojik farklııklardan mı kaynaklandığı, yoksa toplumun her iki cinsiyete yüklediği anlamla mı ilgili olduğu tartışma konusudur (Avcıoğlu, 2007). Nitekim yapılan araştırmalar, cinsiyetlere yüklenen kalıp yargıların da önemli farklııklar taşıdığını ortaya koymaktadır. Toplumlar tarafından tipik bir erkeğin davranışları saldırganlık, duygusal olmamak, baskın olma, rekabetçi, mantıklı, lider, bağımsız olma şeklinde tanımlanırken kadına ait davranışlar ise duygusallık, nazik, empatik olma, konuşkanlık ve bağımlılık şeklinde belirtilmiştir (Taylor, Peplau ve Seers, 1994).

Yurtseverlik Ölçeği'ne verilen cevapların ortalamasının 2,81 olduğu görülmektedir. Yurtseverlik tutumunun hangi değişkenlerden etkilendiğini belirlemek amacıyla, $t$ - testi kullanılarak yapılan ilişkisel analizlerde, araştırmaya katılan öğrencilerin yurtseverlik tutumlarının cinsiyet ve sınıf değişkenlerine göre anlamlı biçimde farklılaşmadığı fakat kendinden farklı kültürden arkadaşların oranı değişkenine göre anlamlı biçimde farklılaştığı görülmüştür. Buna göre öğrencilerin arkadaş grubunda, kendilerinden farklı kültürden bireylerin oranı arttıkça, yurtseverlik tutumları 
da artmaktadır. Bu durum göstermektedir ki öğrenciler kendi kültürel kimliklerin dar sosyal çerçevesinden çıkıp, daha geniş bir sosyal çevre ile iletişime geçmeleri onların, toplumun tamamına karşı bağlılıklarını ve aidiyetlerini kuvvetlendirmekte, bazı kalıp önyargıların önüne geçmektedir.

Anket maddelerine verdikleri cevaplarla öğrenciler, tarih programlarının ve ders kitaplarının kendi kültürel kimliklerini ve dolayısıyla da Türkiye'deki kültürel farklılıkları kapsamadığını ortaya koymuşlardır. Tarih derslerinin kültürel farklılıkları kapsayıcılık konusundaki bu sorunlu durumuyla birlikte, yaşanılan ortak geçmişin bir sonucu olarak tarih programları ülkedeki kültürel farklılıklara sınırlı da olsa yer vermek durumunda kalmıştır. Fakat bu durumda da kültürel kimliklerin tarih öğretim programlarına ve ders kitaplarına yansıma biçimiyle ilgili sorunlar ortaya çıkmaktadır. Araştırmaya katılan öğrenciler tarih derslerinde kendi kimliklerinin ele alınış biçimini rahatsız edici bulmuş ve kültürel/etnik farkııık taşıyan öğrencilere uygun olmadığını belirtmişlerdir. Nitekim dördüncü alt problem çerçevesinde kültürel farklılığa sahip öğrencilerin kendilerine yöneltilen sorulara vermiş oldukları cevaplar, tarih derslerinin kapsayıcılık sorunuyla doğrudan ilişkilidir. Anket sorularına vermiş oldukları cevaplarla öğrenciler, tarih derslerinin kendilerinin Türkiye'ye bağlılığını kuvvetlendirmediğini ve ülkenin bir parçası olarak hissettirmediğini ortaya koymuşlardır.

\section{Öneriler}

- Önyargıların azaltılması, kültürler arası iletişim ve etkileşimin arttırılması amacıyla, ülke genelinde farklı kültürlerden öğrencilerin işbirliğine dayanan eğitim projeleri hazırlanmalıdır.

- Tarih öğretim programları ve ders kitaplarının, etnik merkezci yapısından uzaklaştırılması, kapsamının ülkedeki kültürel farklılıkları kuşatacak şekilde genişletilmesi gerekmektedir. Elbette ki Türkiye'nin tarihi, sadece kültürel farklılıklardan oluşmamaktadır. Bunun için, bu kapsamın genişletilmesinde, çoğunluk kültüre sahip öğrencilerin Türkiye'nin çokkültürlü yapısını kavrayabilmeleri, azınlık kültürlerden öğrencilerin ise, kendilerini tarihsel sürecin, dolayısıyla da toplumun bir parçası olarak hissedebilmeleri, ölçüt olarak belirlenmelidir. Bir tarih öğretim programının kapsamı içerisinde, ulusal tarihin yer bulması kaçınılmazdır. 
- Ülkedeki azınlıkları konu alan belli başlı bölümler, soykırım iddialarına cevap veren ve genç bireyleri bu iddialara karşı donanımlı hale getirmeyi amaçlayan siyasal metinler olmaktan çıkarılmalıdır. Bununla birlikte kültürel farklılıklara yer veren tüm bölümlerin, ayrımcı ve ötekileştirici söylemlerden arındırılması gerekmektedir.

- Toplumun çokkültürlü yapısının, sadece tarih derslerinin konusu olmadığı göz önünde bulundurulduğunda, başta sosyal içerikli dersler olmak üzere tüm öğretim programlarının, öğretmenlerin kültürel ya da yerel farklılıkları vurgulayabilmeleri adına esnek bir yapıya sahip olması gerekmektedir.

\section{Kaynakça}

Avcıoğlu, H. (2007). Etkinliklerle sosyal beceri öğretimi, Ankara: Kök.

Bozkurt, G. (1993). Türk hukuk tarihinde azınlıklar, Ankara Üniversitesi Hukuk Fakültesi Dergisi, Vol. 43 (1-4), s. 49-59.

Breugelmans, S. M. ve Vijver, J. R. (2004). Antecedents and components of majority attitudes toward multiculturalism in Netherlands, Applied Psychology: An International Review, 53(3), s. 400-422.

Büyüköztürk, Ş., (2008). Sosyal bilimler için veri analizi el kitabı, Ankara: Pegema.

Copeaux, E. (1998). Tarih ders kitaplarında (1931-1993) türk tarih tezinden türk islam sentezine, ( Çev. A. Berktay), İstanbul: Tarih Vakfı Yurt.

Çapar, M. (2006). Türkiye’de eğitim ve “öteki türkler”, Ankara: Özgür Üniversite Kitaplığı.

De Vaus, D., (2002). Analyzing social science data, London: Sage Publication.

Giddens, A. (2008). Sosyoloji (Yay. Haz. Güzel, C.), İstanbul: Kırmızı.

Karasar, N., (2005). Bilimsel araştırma yöntemi, Ankara: Nobel.

Kosterman, R. ve Feshbach, S. (1989). Toward a measure of patriotic and nationalistic attitudes, Political Psychology, 10(2), s. 257-274.

Kymlicka, W. (1998). Çokkültürlü yurttaşlık azınlık haklarının liberal teorisi, İstanbul: Ayrıntı. 
Müller, J. W. (2012). Anayasal yurtseverlik, Ankara: Dost Kitabevi.

Okutan, M. Ç. (2009). Tek parti döneminde azınlık politikaları, İstanbul: İstanbul Bilgi Üniversitesi.

Oran, B. (2010). Türkiye'de azınlıklar, İstanbul: İletişim.

Osler, A. (2009). Patriotism, multiculturalism and belonging: political discourse and the teaching of history, Educational Review, 61:1, s. 85-100.

Parekh, B. (2005). Çokkültürcülük nedir? (Çev. Özge Olcay), Bülten, 5, s. 99-109.

Şencan, H., (2005). Sosyal ve davranışsal ölçümlerde güvenilirlik ve geçerlilik, Ankara: Seçkin.

Taylor, S. E., Peplau, L. A. ve Seers, O. (1994). Social psychology, ABD: Perentice Hall.

TCMEB, Talim ve Terbiye Kurulu Başkanlığı (2007). Tarih dersi öğretim programı (9. SInıf), http://ogm.meb.gov.tr/belgeler/tarih9.pdf adresinden 22.09.2013 tarihinde edinilmiştir.

Tekeli, İ. (2007). Birlikte yazılan ve öğretilen bir tarihe doğru, İstanbul: Tarih Vakfı Yurt.

Toth, J. A. ve Vijver, J. R. (2003). Multiculturalism and acculturation: Views of Dutchland Turkish-Dutch, European Journal of Social Psychology, 33 (2), s. 249266.

Tüy, S. P. (1999). 3-6 yaş arasındaki işitme engelli ve işiten çocukların sosyal beceri ve problem davranışları yönünden karşılaştııımaları, Yayımlanmamış Yüksek Lisans Tezi, Ankara: Ankara Üniversitesi.

Yazıcı, F. (2015). Azınlık okullarında tarih eğitimi ve çokkültürlülük, İstanbul: Yeni İnsan.

Yıldız, A. (2010). "Ne mutlu Türküm diyebilene” Türk ulusal kimliğinin etno-seküler sınırları (1919-1938), İstanbul: İletişim. 


\section{Extended Summary}

\section{Purpose}

The purpose of this study, evaluating the views on history courses of students, continued minority schools in Turkey, in the context of multiculturalism and patriotism. Thus, the meaning of the history courses for students from different cultures is aimed to reveal. For this purpose minority students' attitudes about multiculturalism and patriotism, and views about history courses' coverage of cultural differences in Turkey, the role of the history courses forming the sense of patriotism on students from different cultures are investigated.

\section{Method}

In this study, as a survey method, the correlative investigation model is used. According to research design, three data collection tool, Multicultural Attitude Scale, Patriotism Scale and a survey aiming the evaluating of the history courses by student who are the member of different cultural groups are used. Data collection tools are applied to 199 students in 6 minority schools in Istanbul.

\section{Results}

Students who participated in the study gave an average rate as 4,09 to the Multicultural Attitude Scale developed according to 5 point likert type. In correlative analysis made by using $t$-test, multicultural attitudes of female students are positive and meaningfully differentiate according to gender variable. It is seem that the average point of the answer given to Patriotism Scale is 2,81 . In correlative analysis made by using t-test, the patriotism attitudes of students increases when the number of the friends from different cultures they have.

With the answers given by the student to survey items, they revealed that the history schedules and course book are not involving their cultural identity thus, not involve the cultural differences in Turkey. Students find out the consideration of their identities in history lessons disquieting and they said considerations are not appropriate for the students who have cultural/ethnic differences. 


\section{Discussion}

High multicultural attitudes of minority students can be explained for two reasons. First one: in a society that they are not the majority, expectations that the multicultural attitudes and political applications can be dissolve the disadvantages they have. The second reason is the evaluation about living together with the different cultures in a same society without disquiet. It can be evaluated as multicultural attitudes of female students are higher than males, because of the situation about social abilities. The studies say that social abilities of female and male students are different from the early childhood. It's observed that the female students display verbal activities more than males and they display aggressive and disturbing social behaviors less than males (Tüy, 1999). Main reason of this subject is being discussed whether biological differences are the reason or mean of the gender determined by the society.

Differentiation of patriotism attitudes according to the increase of the number of people from different cultures in friend group show that exiting the narrow social context of their cultural identity and communicating with a wider social environment prevent prejudices of students and strengthen the devotion and property against whole society

\section{Conclusion}

The research results show that history curriculum and course books must be removed from their ethnocentric structure. The scope should be expanded to encompass cultural diversity in the country. The main sections about the minorities in the country must be omitted being political texts aiming to equip young generations against genocide allegations. In addition to this all sections about cultural differences must be free from discriminatory and alienating rhetoric 